\title{
Paulo Freire e Agnes Heller: Radicalidade Comunicativa e Educação
} Paulo Freire and Agnes Heller: Communicative Radicality and Education

\author{
LUIZ ROBERTO A LVESa \\ Universidade de São Paulo, Departamento de Comunicação e Artes. São Paulo - SP, Brasil
}

\section{RESUMO}

O autor se reencontra com textos de Freire e Heller, os quais dialogam com o todo das duas obras. Busca compreender o pensamento do educador e da filósofa, ambos sustentados em raízes epistemológicas e objetivos próximos. Sob metodologia de crítica do discurso, dá-se o cruzamento de excertos significativos do patrono da educação brasileira com flagrantes da prática política na obra de Heller. Eles promovem lições políticas para enriquecer uma reflexão sobre o cotidiano educacional brasileiro, especialmente encarnado no dramático percurso formativo do ensino médio, suposto calcanhar de Aquiles da educação básica brasileira. Em Freire e Agnes, a educação se realiza como ação comunicativa radical a serviço da cidadania das novas gerações.

${ }^{\text {a }}$ Professor e pesquisador do Departamento de Comunicação e Artes da Universidade de São Paulo. Fez parte do Conselho Nacional de Educação entre 2012 e 2016. Publicou, entre outras obras, Trabalho, Cultura e Bem-Comum (Annablume; Fapesp, 2008) e Ensaios Sobre o Viável (Editora Metodista, 2017). E-mail: luizrobertoalves99@gmail.com

Palavras-chave: Mudanças no cotidiano, cruzamento de textos, educação, política

\begin{abstract}
The author re-encounters texts by Freire and Heller, which dialogue with the whole of both works. He seeks to understand the thought of the educator and the philosopher, both sustained by close epistemological roots and objectives. Under a critical discourse methodology, significant excerpts from the Brazilian educational patron are crossed with blatant examples of political practice in Heller's work. They provide political lessons to enrich a reflection on the Brazilian educational routine, especially embodied in the dramatic formative course of high school, the supposed Achilles heel of Brazilian basic education. In Freire and Agnes, education is realized as a radical communicative action at the service of the citizenship of the new generations.
\end{abstract}

Keywords: Changes in everyday life, crossing texts, education, politics 


\section{INTRODUÇÃO, OBJETO E OBJETIVO}

\section{Humanização e Humanismo: a originalidade}

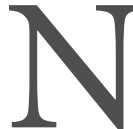
ESTE TRABALHO OS textos de Paulo Freire e Agnes Heller são compreendidos como reflexão em torno das teorias e práticas da humanização. Pensados para o tempo contemporâneo, a obra de Freire e Heller vinca um pensamento necessariamente radical; caso contrário, não teria mais sentidos para a sociedade supostamente mundializada, mas de fato esgarçada e dilacerada pelo modo ultraliberal do capitalismo.

Por certo, as obras são relidas para pensar particularmente o Brasil, que celebra o centenário do patrono da educação. Aqui, Heller é trabalhada por proximidade de pensamento. Nos intercâmbios de significações, será possível ver na conexão Paulo-Agnes as projeções em busca de fecundação da realidade vivida pelas gentes, jovens e adultos, do cotidiano real e seu imaginário de provável mudança.

Nessa perspectiva, quaisquer projetos a cumprir ou conquistar, seja de autonomia ou de constituição cidadã, terão encontros com o humanismo como pensamento filosófico, independentemente das significações históricas que o realizam em vários pontos do pensamento ocidental. $\mathrm{O}$ vasto desenvolvimento das artes e das ciências, da reflexão sobre cenários dramáticos e possibilidades históricas, se implicou em sobressaltos, também seguiu e se mostrou tanto indispensável quanto irredutível, especialmente diante dos horrores e desumanidades.

Em Pedagogia do Oprimido (o Manuscrito) (Freire, 2018), intercambiam sentidos a tarefa humanista, a pessoa humanista, o humanismo, a experiência existencial, a humanização e seu contrário, o estar no mundo para mudar-se e mudá-lo, a dialética subjetividade e objetividade, a condição de sombra do eu e a adesão ao opressor, o diálogo e a revolução. À página 19 do manuscrito fica claro que a pedagogia do oprimido é humanista e libertária. E à página 29, para não citar muitos outros exemplos, o humanista "se reconhece mais por esta crença no povo, que o engaja, do que por mil ações sem ele”.

Não há razões para pensar que o patrono articule vocábulos e sintaxe de modo aleatório. Nunca o fez. Foi rigoroso e preciso no limite. Pesou e sopesou os vocábulos para deles extrair acúmulos de sentidos em movimento conectivo. Nesse sentido, seu entendimento de humanização supera quaisquer dicionários, pois ele o coloca num processo revolucionário. Freire trabalhou com valores humanos na História e, por isso, questionou idealismos e tecnologismos, mas não o humanismo, que se realiza na História e com o qual Paulo trabalhou de modo primoroso. Como teria de ser, a humanização é o ápice do desenho de próprio punho que ele apresenta à página 157 do manuscrito de Pedagogia do Oprimido (Figura 1). 


\section{Figura 1}

Diagramas elaborados por Paulo Freire

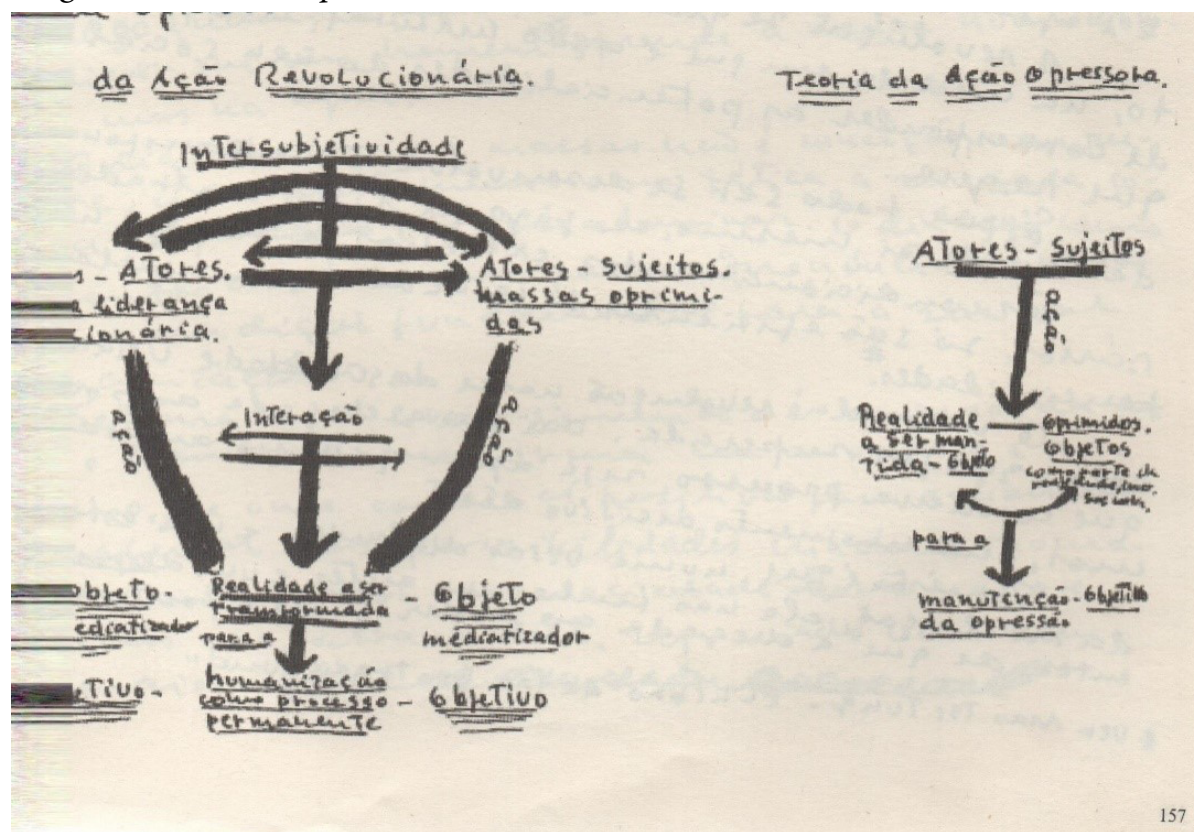

Nota. Reproduzido de Pedagogia do Oprimido (o Manuscrito) (p. 157), de P. Freire, 2018, Editora e Livraria Instituto Paulo Freire; Universidade Nove de Julho (Uninove); Big Time Editora/BT Acadêmica. Copyright do autor.

A relação entre Heller e o humanismo renascentista vai além do amor que ela dedicou à Itália, pois se garante em obra básica publicada em 1967, O Homem do Renascimento (Heller, 1967/1982), um tipo de criação-aprendizado que não a abandonaria jamais. Esse livro foi necessário para um outro conjunto de textos sobre esse homem renascentista publicado em 1988 sob a coordenação de Eugenio Garin. Este resume bem o pensamento de Heller:

Em seu poderoso tratado, precisamente intitulado O homem do Renascimento, publicado em Budapeste no ano de 1967, Agnes Heller, discípula de Lukács observou que o Renascimento foi aquela "idade das grandes biografias", de fato da autobiografia. E isso, acrescentava, porque tantas personalidades excepcionais se formavam em uma sociedade que se construía, se transformava e se recontava. A um momento estático - continuou Heller - sucedia um momento dinâmico. O homem novo, o homem moderno, era consciente de sua feitura, fazia-se. Era esse o "homem do Renascimento"'. (Garin, 1988/1993, p. 6)

Esse fazer-se, essa exigência da consciência do seu lugar e do lugar de sua gente - outros e outras - e essa indispensável dinâmica conscientizadora na
${ }^{1}$ No original: "Nel suo massiccio trattato, intitolato appunto L'Uomo del Rinascimento, uscito a Budapest nel 1967 , Agnes Heller allieva di Lukacs ha osservato che il Rinascimento è stato 'letà delle grandi autobiografie', anzi letà delle autobiografie. E ciò, aggiungeva, rerché tante personalità eccezionali si venivano formando in una società che si costruiva, si trasformava e si raccontava. A un momento statico continuava la Heller era succeduto un momento dinamico. L'uomo nuovo, l'uomo moderno, era un uomo che si veniva facendo, che si costruiva, e che era cosciente di questo suo farsi. Era, appunto, 'luomo del Rinascimento". Esta e demais traduções, do autor. 


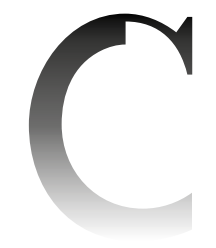

${ }^{2}$ Cabe lembrar que Garin coordenou a obra L'Uomo del Rinascimento (1988/1993). O mestre Jacob Burckhardt escreveu A Cultura do Renascimento na Itália (1868/2009), edição brasileira da Companhia das Letras. direção do homem novo (que Freire radicaliza na revolução humanizadora) será seu aprendizado e sua práxis, notadamente a partir do cotidiano.

Fique claro que a existência e a dinâmica do pensamento humanista não implicam dourar a pílula do humano. Garin (1988/1993) busca corrigir o otimismo de Burckhardt sobre o humanismo renascentista italiano quando mostra que "o mestre suíço não notou a crise e a transformação das sociedades e a inserção de tipos múltiplos em múltiplas inserções sociais" (citado em Alves, 1997, p. 40). Claro que o humanismo é muito mais do que o esplendor da Capela Sistina. Garin continua a argumentar no sentido de que

tratar do nascimento do homem novo não prescinde da análise de suas formas de corrupção e de degeneração, quer da crueldade dos tiranos e seu competente uso das formas e instrumentos de guerra, da definição de espaços e das novas formas de ação política². (citado em Alves, 1997, p. 41)

Tanto os artistas do humanismo podem tornar-se bizarros quanto os pensadores humanistas podem vir a ser pedantes.

Não se pretende afirmar que Heller e Freire são exemplos do pensamento humanista. Mas importa ver o movimento de suas obras, que encontram nas incompletudes, no desvendamento das possibilidades humanas, na liberdade de enunciação para além do selo ideológico colado na testa, o lugar da vida em processo de libertação, via novos olhares, falas e oitivas, via encontros e reencontros com os outros, com as outras e os lugares em que natureza e cultura enunciam seu destino e revelam seu inacabamento.

Seria possível citar vários pontos da obra de Freire e Heller nas quais convergências revelam o humanismo. Algumas célebres citações em Pedagogia do Oprimido (o Manuscrito) (Freire, 2018) já foram expostas. Certamente o humanismo em Freire, já bem estudado, não carece de essências ou ideias supostamente puras para ser móvel indutor de autonomia, liberdade, direitos e cidadania vivida, sempre confrontadas com a opressão. A sequência do artigo esclarecerá, mas há dois lugares privilegiados das obras estudadas que exigem demonstração imediata. Em Freire, o pequeno-grande livro Educação e Mudança (1979/1983), lançado ao público quando Paulo retornava do exílio de 14 anos. Entre as páginas 27 e 32 tem-se um discurso necessário para tudo o que se lerá em Freire, inclusive nos textos inéditos e publicados depois de sua travessia em 1997.

Embora, com certa razão, Moacir Gadotti (1979/1983) ataque no prefácio o humanismo idealista e o humanismo tecnológico em educação, a atitude crítica diante da natureza do homem inacabado e, portanto, necessariamente 
educável, é uma atitude humanista, fenômeno da humanitas, nem idealista, nem servilmente tecnológica. E não existe receio da polêmica. Daí, tem-se que: "O homem deve ser o sujeito de sua própria educação. Não pode ser o objeto dela. Por isso, ninguém educa ninguém" (Freire, 1979/1983, p. 28). Noutros pontos da obra surgirá a mediação do mundo e um intenso processo de comunicação desse humano perguntador, que o levará ao outro, à outra, aos encontros com os próximos, ponto de partida do aprender, da conquista da autonomia e da liberdade. Aí se estabelece o direito de ser cidadão, cidadã. Nesse movimento, que também é de conquista, a pessoa se faz ser da urbe.

A comunicação que media esses atos e implica várias leituras da palavra $\mathrm{e}$ do mundo terá de ser radical para promover educação, não como quantidade de atos comunicativos, mas fundamentalmente como qualidade das conexões escolhidas, pensadas, julgadas a partir da base cultural comum e da leitura de classe da comunidade educadora, incluído aquele que pensa e escreve. Os atos comunicativos que promovem educação não podem ser mitigados, censurados, semiabertos, com livros, práticas cotidianas e documentos fechados e pessoas temerosas em se expor. Liberados em suas escolhas pelo lento aprendizado que move a consciência, os comunicadores e as comunicadoras se educam, de Angicos ao futuro, tendo em vista um Brasil liberado, autônomo e encarnado em suas maiorias tantas vezes violentadas. Educamo-nos, pois, na radicalidade comunicativa, que também é uma radicalidade sociológica e política.

Em Heller (2012), um texto arguto sobre Marx e as necessidades humanas apoia o projeto de humanização. Na obra italiana da filósofa húngara (cit.) desenvolve-se um capítulo encabeçado pelo título: "Marx Sem 'Ismo' e as Necessidades Radicais do Homem". Depois de afirmar que Marx não era marxista ela demonstra que aprendeu muito com os acontecimentos de 1968, de modo a repensar necessidades e interesses humanos à luz do pensamento do criador de O Capital. O motor de seu trabalho, segundo Heller, eram as necessidades radicais do proletariado, que não poderiam ser satisfeitas pela sociedade do lucro e da exploração do trabalho. Animada pelos gritos da juventude, Heller redefine as necessidades humanas: elas são qualitativas, não admitem subordinações, exigem o desenvolvimento radical do humano rumo a uma vida cheia de sentido, com tempo livre, trabalho digno e gratificante, amor, contemplação, beleza e emancipação. A juventude era a voz das necessidades radicais e ela se sentia no direito de fazer uma nova hermenêutica em Marx.

A utopia seria feita realidade. É bem verdade que mais tarde Heller (2012, pp. 75-86) escreve textos algo desconfiada da satisfação de todas as necessidades radicais das pessoas, talvez estranha a qualquer sociedade. Preferiu a filósofa pensar um mundo que o humano, indivíduo e grupo, possa moldar 


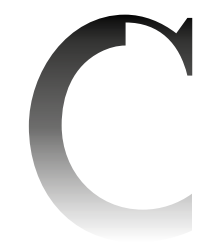

${ }^{3}$ No original: "En tout cas, ce que nous pouvons dire dès le début, cest que nous entendons par existentialisme une doctrine qui rend la vie humaine possible et qui, par ailleurs, déclare que toute vérité et toute action impliquent un milieu et une subjectivité humaine". como possível, sem uniformidade, sem definição. Não acabado. Deste modo, parece surgir um novo ideal para ela. Trata-se do homem e da mulher que, mais tarde, se vira para trás e pensa que fez tudo o que lhe era possível realizar. $\mathrm{O}$ antigo homem do Renascimento tratado por ela também fazia e constituía a ação, contemplava e laborava sua liberdade. Fazia-se. A superação das engrenagens do consumismo e das novas formas de exploração revelarão as possibilidades na história... Aí o dever-ser cria relações fortes com o dever-fazer.

Freire e Heller promovem intenso diálogo em seus textos. A humanização é o eixo.

Não convém esquecer que, desde os desdobramentos do longo debate medieval em projeto humanista a história nos revela escombros, crises de toda espécie e revoluções, tão bem revistas por Eric Hobsbawm (2007). No entanto, caminham pelo tempo secular (e também sofrem) dois valores constituintes e instituintes de novos passos do humano: a possível consciência do real, com suas potencialidades, e o crescimento da pessoa em emoção e conhecimento. Educação, Ciência e Consciência. Sartre (1970) reclamou que era criticado porque afirmava ser o existencialismo um humanismo e, ainda assim, colocava ênfase no lado negativo da vida humana. Ora, disse Sartre: "O que podemos desde já afirmar é que concebemos o existencialismo como uma doutrina que torna a vida humana possível e que, por outro lado, declara que toda verdade e toda ação implicam um meio e uma subjetividade humana"3 (p. 12).

$\mathrm{Na}$ intensa elaboração de seu texto-cavalo-de-batalha, que busca responder a um a um dos questionamentos feitos contra o existencialismo, Sartre (1970) chega ao humanismo. Nega aquela tendência humanista que faz do homem o ser admirável que realiza muitas coisas e, portanto, vira um paradigma em razão de seus atos mais elevados.

Assume, porém, outro sentido de humanismo. O humanista está sempre por fazer e não se realiza como paradigma para assumir julgamentos sobre outros. Nesse humanismo o homem transcende (não na direção de Deus e sim do mundo-humano) e assume toda a subjetividade de ser e estar no mundo, sabendo que o universo único que existe é o humano. Importante, destaca Sartre (1970), é que não convém voltar para si mesmo, mas construir metas fora de si, por exemplo a liberdade e quaisquer outras realizações que signifiquem sua humanidade.

Os projetos de Sartre não são os freirianos ou aderentes a Heller, mas há componentes em diálogo quando o valor trabalhado pelos três faz florescer sentidos na tarefa emancipatória, na missão libertadora, no dever-ser e no dever-fazer. 


\section{SENTIDOS PRIVILEGIADOS}

O trabalho de Freire e Heller se realiza por meio de um privilégio de sentidos físicos, em cuja distinção tanto se define a área de saber quanto a leitura do que entendem ele e ela como valor de interlocução social.

Do lado da autora do cotidiano na história, o olhar, o clarificar; quanto ao patrono da educação brasileira, as falas que suscitam diálogos em busca de significações políticas, sinônimo de ação revolucionária. Uma discursa pelo olhar e o outro discursa na conversa intuída e desejada. Trabalham-se sentidos privilegiados para esclarecer e para estimular a construção de conhecimento e sua consciência.

Cabe apresentar os documentos trabalhados. Na leitura italiana de Heller (1972/2011), denominada "La Teoria, la Prassi e i Bisogni Umani", ao iniciar o texto que a levaria a discutir as necessidades humanas sob a sociedade da mercadoria, tem-se como disposição “avere ben chiaro" (ter clareza) (p. 28) que trata da sociedade burguesa nos tempos modernos. De imediato, afirma ser necessário "chiarire" (clarear, esclarecer) (p. 28) que tratará de ciências humanas. Cabe, portanto, agregar a leitura de La Sociologia de la Vida Cotidiana (Heller, 1970/1977), com ênfase para os textos entre páginas 9 e 90 . O conjunto escolhido é temático, pois move os sentidos do corpo, que são metabolizados na direção da existência significativa no mundo e na vida, entre percalços e afirmações. Nesse texto, ainda no prefácio, o mestre György Lukács (1970/1977), ao apresentar a metodologia de escritura de Heller cria uma figura exemplar, representativa da construção genérica da discípula: "que se eleja um método genérico a iluminar os caminhos que os diversos modos de reagir percorrem, a partir do momento em que afloram espontaneamente até o momento em que adquirem uma imagem/compleição plena"5 (p. 12).

$\mathrm{Na}$ obra análoga de 1970, traduzida como O Cotidiano e a História (Heller, 1970/1985, pp. 28, 36, 69, 85, 99) ${ }^{6}$ o pensamento "faz ver, evidencia, é visto e vê" em seus momentos decisivos.

No seminário mundial sobre Paulo Freire, em Turim, 2014, este ensaísta se encontrou com Heller, que discutiu alguns aspectos do processo de humanização na obra do educador e apresentou seu livro, de 2012, I Miei Occhi Hanno Visto ${ }^{7}$ (Heller, 2012).

A obra é uma longa entrevista realizada em um monastério próximo a Verona. Considera Auschwitz, Hiroshima, Lukács, Marx, sua vida nos Estados Unidos e a própria filosofia, de interesse especial para o presente ensaio.

Os capítulos privilegiados por este ensaio para o olhar contemporâneo são: "Lukács, as Vacas e a Escola de Budapest" (Heller, 2012, pp. 57-74) e "Marx Sem 'Ismo’ e As Necessidades Radicais do Homem” (Heller, 2012, pp. 75-86).
${ }^{4}$ A primeira edição húngara foi de 1970. Por Edicions 62, de Barcelona, saiu em 1977 e 1987. Na edição catalã Heller afirma que não tem $o$ que acrescentar ao trabalho de 1970. O prefácio é de Lukács.

${ }^{5}$ No original: "se elija un método genérico, iluminando así con claridad el camino que recorre los diversos modos de reaccionar desde el momento en que afloran espontaneamente hasta que adquieren una figura completa".

${ }^{6}$ Cabe aqui a homenagem à editora Paz e Terra, que publicou a obra em 1985. O livro se constitui de variações focadas no problema central do cotidiano.

${ }^{7}$ Livro-entrevista com Francesco Comina e Luca Bizzarri. O trabalho entre Heller e os entrevistadores se deu na Páscoa de 2012. 


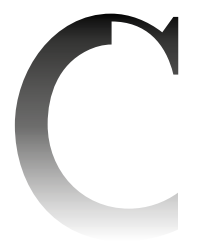

${ }^{8} \mathrm{O}$ poema, sem nome, abre o livro. Foi composto em Genebra, abril de 1976.

${ }^{9}$ Trata-se da cópia de segurança feita por Paulo Freire e deixada em mãos do ministro de Salvador Allende Jacques Chonchol e sua esposa Maria de Oliveira Ferreira, na primavera de 1968. Na dedicatória ao casal Freire (2018) conclui: "Queria que vocês recebessem estes manuscritos de um livro que pode não prestar, mas que encarna a profunda crença que tenho nos homens, como uma simples homenagem a quem admiro e estimo" (p. 37).

A leitura dessas propostas de iluminação do mundo sugere outro modo de representação do caminho humanizador, o texto poético de Freire, sem título, inserto em obra póstuma organizada por Nita Freire (Freire, 2001) ${ }^{8}$ - reproduzido no Apêndice deste artigo. Ali, tem-se $o$ estrangeiro, que se mantivera em silêncio e, quando falara com o povo do vale, tratara da natureza e seus movimentos de beleza; no entanto, uma outra fala se inaugura, um "agora vos digo" que vai até o final, evangélico, a buscar na palavração um discurso tão diferente quanto permanente, um discurso de libertação. Agregue-se à análise a sequência do livro Pedagogia do Oprimido (o Manuscrito) (Freire, 2018) ${ }^{9}$. Tal sequência, pelo testemunho dos organizadores da obra reescrita à mão por Freire em 1968, não consta das traduções conhecidas, pois foi retirada das edições pioneiras em língua inglesa. A teoria do movimento revolucionário que Freire (2018) desenvolve (pp. 156-158) apresenta dois desenhos, um da ação revolucionária e outro da ação opressora. Um vai das intersubjetividades (intercomunicação) às transformações e à objetividade da humanização, via interação. O outro se realiza a partir dos atores-sujeitos em direção à objetividade da manutenção opressora, via construção de sujeitos-objetos.

Como se sugeriu, esse discurso em Freire (2018) não produz um paradigma metafórico, mas felizmente um eixo metonímico, que vai das partes fragmentadas da sociedade em busca de um sentido organizador, um conhecimento alimentado por pedagogia libertadora, que sempre permite fazer o movimento de retorno ao homem e à mulher, às pessoas das classes desprezadas, capazes de juntar em si a humanidade necessária para a vida no mundo.

Este trabalho de leitura textual e compreensão de pensamentos, a partir do vivido e sentido do cotidiano, trabalhará correlações no quadro da obra de cada autor, considerados elementos do processo histórico-social. Na medida do possível, o trabalho de descrição e análise projetará as significações correlacionadas à contemporaneidade, especialmente sobre situações da educação, da cultura e da comunicação.

\section{METODOLOGIA}

Este trabalho considera Chartier (1990, p. 227), que nos ajuda a criar indicadores para a leitura e para a avaliação. Para ele, há dois enfoques na leitura analítica dos textos: de um lado a morfológica, que trabalha movimentos de conceitos e as figuras que os explicitam; de outro a sintática, que trabalha a especificidade das normas, regularidades e situações próprias da obra considerada. Nesta análise, o corpus textual é conduzido pelo olhar (Heller) e pelo diálogo (Freire), que induzem às construções frasais, quer na obra argumentativa, quer no poema. 
O corpo morfológico-sintático, com sua presença de olhares e diálogos, suas figuras, presenças/ausências, recorrências, constitui o corpus alargado em Bauer e Aarts (2002, pp. 50-51).

Aplicados os enfoques de Chartier (1990) ao corpus alargado (os dados do mundo vivido, as ideias, as imagens e os projetos de mudança), vê-se também o lugar de conhecimento onde trabalha o leitor-crítico. Nessa relação se cria um processo de comunicação, o qual participa do conhecimento do mundo e das suas possibilidades de mudança.

Essa leitura metodológica ganha coerência no modo de fazer do autor e da autora trabalhados. Segundo a filósofa do cotidiano, trata-se de eleger um método e com ele iluminar os passos que levam à consciência política. Tal método se move do genérico individual (corpus restrito) para o corpus alargado, no qual a consciência de homologia entre desafios e forças sociopolíticas habilita o ser do cotidiano a novos confrontos, aprendizados e conquistas. Entre muitas imagens recorrentes, a maneira de construir na poética freiriana assume falas espontâneas sobre a natureza e a cultura locais do povo do vale, que se organizam como corpo inicial que oferece espaço para o discurso segundo e o terceiro. $O$ primeiro deles se inicia por conjunção adversativa ao modo evangélico (mas agora voz digo...), a qual busca superar a consciência ingênua ${ }^{10}$. O próximo trata de atingir a figura completa, transversal a toda a obra do patrono da educação brasileira (coerente com o alcance da força política em Heller). Essa conquista de imagens e símbolos pela palavra dialogada se realiza com palavração, discurso diferente e permanente, fenômeno original da consciência crítica segundo Freire. Cabe ver, pois, como se move cada corpo textual rumo ao atingimento de seus alvos.

\section{CORRELAÇÕES}

Estabelecidos os textos e os modos de fazer dos autores (a visão e o diálogo), a par das bases metodológicas capazes de melhor elucidá-los, carece-se de aprofundar as correlações entre texto e processo construtivo, com vistas ao direcionamento de suas significações na história.

No excerto publicado, originalmente em 1972, e também em italiano na revista AUT-AUT no ano seguinte, Heller (1972/2011, pp. 28-30) questiona a teoria que resulta da divisão do trabalho e que ganha força na sociedade burguesa por meio de sua divulgação, seu marketing. Não deixa de observar que há certa precariedade na relação entre os criadores de teoria e seus utilizadores, quer pela manipulação das forças do mercado, quer pela mera funcionalidade da teoria, que dirige setores da sociedade por meio de alguns modelos e em direção a pontos limitados pré-estabelecidos. Ocorre, pois, que teorias
${ }^{10}$ Talvez os trechos mais ricos de Freire sobre a ideia de consciência ingênua (e em consequência seu contrário) sejam aqueles em que pensa diretamente o trabalho do educador no contato com seus estudantes. Em Pedagogia da Autonomia (Freire, 1996, p. 122), ele combina o inacabamento da pessoa jovem à sua condição passiva de quem recebe conteúdos para guardar e talvez responder segundo se exige. Lembra, pois, a antiga reflexão sobre o depósito bancário. O inacabado natural e o passivo cultural constituem a consciência ingênua, tema central da educação entendida como ato político. 
são apresentadas e aceitas no processo de comunicação como produtos de higiene, tipos de pastas de dente. Nesse movimento de ideias, destacam-se dois pontos: o sentido de práxis e a eficácia da teoria. Heller chama a atenção para a necessidade precípua de não entender práxis como qualquer atividade humana, de que decorre a própria eficácia da teoria.

Por sua vez, o texto traduzido por Carlos Nelson Coutinho e Leandro Konder O Cotidiano e a História (Heller, 1970/1985) apresenta o desenvolvimento das ideias do excerto, na medida em que "a estrutura da vida cotidiana está caracterizada basicamente pela muda coexistência de particularidade e genericidade" (Heller, 1970/1985, p. 23). Impressiona a forma do capítulo especialmente tratado na obra: 50 parágrafos descritivos do que é a vida cotidiana, com alguma argumentação adversativa a favor da construção do "humano genérico", acima da consciência do dia a dia repetitivo. Os últimos seis parágrafos começam a demonstrar que a vida cotidiana não é, necessariamente, alienada como definição, pois houve representações históricas não alienadas, especialmente ligadas à ciência e à arte. Então, a orientação do texto se faz pelos verbos possibilitar, significar, supor, tornar, engajar, descobrir, dever, converter-se, empenhar-se (Heller, 1970/1985, pp. 17-41). No entanto, a despeito de o pensamento cotidiano ser dirigido pela espontaneidade, o humano cotidiano não está imune de se constituir parte da práxis a partir de sua atividade prática. Esse momento humano-genérico da consciência, que é a práxis, é capaz de construir o novo.

A considerar Chartier (1990), essa cultura que busca tornar-se genérica opera uma gramática de muitos textos, ainda que fragmentados. Os discursos do novo bem-estar social da sociedade liberal, operados em vários momentos da governança deste século, especialmente por meio de reformas e, especialmente, desafios individualistas, tanto sinalizam o movimento paradigmático de novas teorias do welfare state como, principalmente, o trabalho precário e terceirizado para inundar o cotidiano e evitar um efetivo processo dialógico. Num momento, instituições e organizações mediadoras da sociedade, como sindicatos e outros formadores de opinião se encantam com o discurso dos governantes e decalcam sua linguagem no cotidiano popular. Noutro, as cisões se aprofundam, mas as operações de marketing ainda assim operam o esforço em fazer seus discursos passarem da representação de mundo (ou uma apresentação dialogada com a sociedade) para se tornarem significação, não para os agentes governamentais de discurso (que barganham falas, moedas e poder) e sim para reconstruir o cotidiano da sociedade, o que é a práxis.

Heller (1970/1985, p. 24) exemplifica a cessão de um lugar no transporte coletivo para a mulher idosa e Freire muitas vezes suscitou o diálogo em torno das palavras do cotidiano que associam o eu ao nós, como tijolo, casebre, enxada, 
lápis etc. Ambos entenderam ali a possibilidade (não a compulsoriedade) de ascender do cotidiano para completar figuras genéricas de moral, generosidade, encontro com o outro e mudança, o que pode levar a relações sociais criativas, portanto competentes para serem políticas.

Em exercício, ou práxis, de representação similar, o estrangeiro do poema de Freire começa a falar com o povo do vale sobre o cotidiano, suas manhãs, os cânticos dos pássaros, suas incertezas, negações, trabalho, alienação. Essas falas significavam um "aprendizado fundamental", ou seja, as palavras e frases formais do exercício da linguagem não comportam os sentidos de imediato, no seu próprio surgimento. As camadas de significação vão-se fazendo história inclusive na suposta alienação, que implica falar de pássaros e flores. Nesse movimento, não há palavras de ordem, nem discursos negadores do diálogo. Tratava-se de um "falar a vós" como "forma de falar convosco". Segue-se em tonalidade evangélica a ampliação da sintonia entre o eu e os outros. Nem mesmo a suposta alienação das conversas anteriores significava fraqueza permanente e sim equalização discursiva, necessária. A fraqueza sentida no cotidiano do "povo do vale" não foi "presente dos deuses", nem "perfume das flores". Trata-se de não acreditar que a "fraqueza não é ornamento de nossas vidas amargas". Em seguida, propõem-se duas virtudes hauridas no cotidiano em transformação: "não acreditar" em quem impõe a naturalidade da alienação/fraqueza, mas "esconder" dos poderosos, como tática, o que já sabemos, ao menos por um tempo determinado, pois eles precisam continuar a acreditar que o "povo do vale" nada sabe e nada conhece. Enquanto isso, prepara-se o discurso "que sacudirá montanhas e vales", isto é, o discurso diferente (a "nossa palavração"), que será um discurso permanente. E cabe a profecia: "Ai de nós, porém, se pararmos de falar/Somente porque eles já não possam mais mentir". O discurso de libertação sempre "estará sendo".

As formas temporais do advérbio comandam o poema: depois, apenas. Mas somente até o início do discurso dialetizante. Os advérbios dão passagem para verbos de ação e assim os comandos se alteram, somente pontuados por conjunções adversativas (especialmente mas, porém) indispensáveis para chamar a atenção para recidivas da consciência ingênua. Ao se aproximar do final, o poema se fortalece pela locução por isto, que tem a força dupla da conectividade advérbio e conjunção. Por isto vos digo: aí se define que o discurso diferente, libertador, é uma palavração que terá de ser permanente. Palavração também pode ser revolução.

O estrangeiro, que se faz liderança revolucionária depois de se assumir ser do cotidiano, é o líder revolucionário das páginas do manuscrito (Freire, 2018, pp. 155-157) anteriores ao desenho de Freire, que não consta das traduções.

Primeiramente (o tom bíblico circula nos dois textos), ao contrário do processo opressor, no qual as elites se alimentam da "morte em vida" dos oprimidos, 


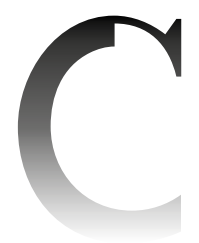

${ }^{11}$ No original: "la consciencia del nosotros no constituye siempre una antíteses de la consciencia del yo. Los sentimientos relativos a la consciencia del nosotros pueden ser afectos particulares precisamente como los referidos a la consciencia del yo".

${ }^{12}$ No original: "sólo cuando el hombre ha reconocido y organizado sus 'propias fuerzas' como fuerzas sociales, y por ello ya no separa de sí la fuerza social en la figura de la fuerza política". o caminho da liderança revolucionária é "morrer para reviver através dos oprimidos e com eles". O estrangeiro do poema se nega para, em momento fundamental, falar com o povo na etapa do aprendizado fundamental. O aprendizado implica conhecer, também, as negações e alienações, que se mesclam ao cântico dos pássaros e ao suceder das manhãs, fenômenos do cotidiano. Lê-se "os homens se libertam em comunhão" (Freire, 2018, p. 154). Ato contínuo, a convivência da liderança revolucionária com os oprimidos (constituinte da generosidade) se desvencilha das amarras da reificação e, ao negar palavras de ordem, constitui um discurso na primeira pessoa do plural que caminha para um movimento de discurso-práxis de libertação.

O desenho de próprio punho de Freire (vide Figura 1) traz duas imagens: a teoria da ação revolucionária e a teoria da ação opressora. A primeira passa pelas intersubjetividades em contato, passa pela interação de sujeitos atores (lideranças e massas oprimidas) e chega ao objetivo da humanização, que enfrentou a realidade a ser transformada conjuntamente. Ao fim e ao cabo, tem-se a humanização como processo permanente. A segunda, de seu lado, se inicia pelos sujeitos atores, vai a uma ação em que os oprimidos são uma realidade a ser mantida e se dirige ao objetivo da opressão. Portanto, uma figura mais simples. Não comporta uma quantidade representativa de atores, não porta realidades a serem transformadas e não leva a qualquer forma de humanização. A partir da página 43 de La Sociologia de la Vida Cotidiana, Heller (1970/1977) estuda o fato de que "a consciência do 'nós' não constitui sempre uma antítese da consciência do 'eu'. Os sentimentos relativos à consciência do 'nós' podem ser afetos particulares precisamente como aqueles referidos à consciência do 'eu"'11 (p. 44). Entre citações privilegiadas de Marx e Goethe (algumas vezes de Platão e Aristóteles) a autora continua sistematicamente a afirmar, em momentos chaves do seu texto, que carecemos de ter presentes o particular que se orienta na vida cotidiana e o mundo no qual ele precisa se orientar, isto é, supõe-se como chave de leitura o olhar orientador.

Enfim, para o que interessa a este trabalho, Heller (1970/1977) cita Marx de $A$ Questão Judaica para dar a orientação rumo à emancipação humana, isto é, ela se dá: "somente quando o homem reconhece e organiza suas 'próprias forças' como forças sociais e por isso já não separa mais, em si mesmo, a força social da figura da força política" ${ }^{12}$ (p. 90).

\section{A CONDIÇÃO DO ENSINO MÉDIO E O INÉDITO IMAGINADO}

Alguns fenômenos do momento educacional que vivemos permitem correlações produtivas junto aos textos de Paulo e Agnes. A reforma da educação 
média brasileira e a escola sem partido encarnam o quadro desafiador das representações e levam à discussão da consciência e da ação do "estrangeiro poético", que também converge para os indicadores de consciência.

Mesmo sem um debate amplo sobre a condição da adolescência brasileira (três milhões fora da escola, alguns milhares apenados por reincidência de infrações e alto índice de mortalidade entre os mais pobres), à luz do fenômeno já vivido e conhecido do desempenho medíocre dos estudantes brasileiros nos exames massivos do Pisa, o Ministério da Educação (MEC) lança em 2016 uma Proposta de Emenda à Constituição (PEC) salvadora do ensino médio brasileiro. Ela propõe aos 27 sistemas de ensino da federação um orçamento reduzido associado a um repertório de ofertas de componentes curriculares segundo as possibilidades de cada sistema e até de cada município e comunidade escolar. Portanto, uma ação de longo prazo e sujeita a muitas variações.

No entanto, o uso do marketing midiático foi intenso e produziu a imagem de que tudo está acontecendo ao mesmo tempo, um tempo mítico, ou que a redenção desta etapa educacional já chegou. De fato, o projeto de TemerMendonça não saiu do papel, pois deveria, em tese, ser iniciado quando a pandemia do Sars Cov 2 nos atacou. Destaque-se que esse governo resultou de um golpe parlamentar aplicado no governo de Dilma Roussef em 2016 e, portanto, não garantiu nenhuma credibilidade e levou o país ao governo Bolsonaro. Decorre que, depois de mais de dois anos, não há previsão para a aplicação das Diretrizes para a Formação Inicial e Continuada do Magistério, criadas pelo Conselho Nacional de Educação no final do governo anterior em atendimento ao Plano Nacional de Educação, 2014. No atual governo não há uma única política educacional que encaminhe uma efetiva mudança do ensino médio, a considerar a grandeza do país e a atomização das unidades escolares no território.

Ora, são conhecidas as precariedades do magistério brasileiro da educação básica, depois de 50 anos de formação feita ao sabor das teorias de plantão, dos currículos mínimos, da volúpia do mercado educacional e dos direcionamentos apostilados na organização didático-pedagógica.

Apesar disso, a condição do ensino médio nacional não evitou a formação de organizações mediadoras fortes nos espaços do magistério, as quais, no entanto, seguem pautas pragmáticas, salariais, assinaladas por conquistas sofríveis. A exceção é a Conferência Nacional de Educação (CONAE), depois transformada em Conferência Nacional Popular de Educação (CONAPE), criada posteriormente à devassa do Fórum Nacional responsável pela conferência realizada pelo governo Temer. Nela (edições de 2010 e de 2014) eixos fundamentais da educação básica brasileira são trabalhados coletivamente e documentos referenciais levam à efetiva constituição de políticas educacionais. 
Ligam-se, pois, os fenômenos. A precariedade acumulada de todo o processo formativo, a desorientação de diretrizes e a expansão mercadológica dos serviços educacionais se encontram com a negação da escola diversa e construtora de cidadania. O cotidiano do trabalho escolar é uma espécie de drama brasileiro a ser redimido, mas ainda não se fazem ver consciências estruturantes do real vivido e seu devir.

No entanto, esse nível educacional sofre um esquartejamento similar ao que sofre toda a juventude no sistema de divisão de trabalho neoliberal - o novo exército da suplência - e, no entanto, faltam forças, quer de educandos, quer de profissionais da educação e centrais sindicais, para novos passos transformadores da condição presente, piorada ainda mais com a pandemia. A rigor, o que nos trouxe Freire, a libertação em comunhão, a chegada à humanização pela consciência da condição vivida e o aprendizado como fenômeno dos encontros e confrontos com os outros e o mundo, tudo isso é estranho ao ensino médio que se conhece e que nada muda com a suposta reforma do governo transitório que desembocou em Bolsonaro. Hoje já se clama nas ruas pela revogação da lei que criou o suposto novo ensino médio. Reconheça-se que esse conjunto social e humano denominado ensino médio é um tempo-espaço de tremenda pressão sobre a adolescência em face de um futuro que já chegou e que faz um questionamento de esfinge prestes a devorar o adolescente em direção ao mundo do trabalho "flexibilizado", isto é, desmantelado e operado por tecnologias pouco conhecidas. Entendido o quadro dessa etapa da educação básica brasileira, fica-se distante do projeto de mudança proposto por Heller (1970/1977, p. 90): "reconhece e organiza suas 'próprias forças' como forças sociais e por isso já não separa mais, em si mesmo, a força social da figura da força política". Trata-se da elaboração originalmente proposta por Lukács (1970/1977, p. 8) para a leitura da vida cotidiana de Heller. Ou essa condição ameaçada e silente, que não favorece os encontros e os confrontos propostos em Freire e rumo a um novo tempo palavrador, conectivo, dialogante.

O problema é que essa imagem do ensino médio diante de exames em larga escala e seus resultados medíocres em linguagens e matemática deixa de auscultar um sujeito fundamental do processo: o estudante, a estudante. Especialmente essa gente em formação no interior de seus territórios, suas famílias, suas comunidades, seus modos de pensar a escola e a sociedade e suas leituras de si mesma. Se essa oitiva inexiste, a fragmentação, o silêncio e o desencanto serão mantidos e a marcha dessa etapa escolar parecerá única, ruim e inflexível.

Não é sem razão que se queira banir no atual desgoverno a leitura de gênero e inaugurar a famigerada escola sem partido ou buscar privilégio e ocultação no homeschooling. Isso, ao mesmo tempo em que se bate na tecla dos direitos de escolha de percursos formativos dos adolescentes nesta fase de novo ensino médio. A rigor, 
aquele ou aquela que deve fazer escolhas não tem como garantia sequer o reconhecimento de sua condição efetiva de pessoa e cidadão, a quem a Constituição garante direitos de opinião, estudo, palavra e posicionamento político. Se a adolescência está proibida de se definir como pessoa em si e sujeito de direitos, ainda não está dada a mínima compreensão das forças pessoais como forças sociais em direção às forças políticas. Ora, escolhas curriculares nessas condições equivalem a atos mecânicos e sinais de imposição tecno-burocrática. Noutras palavras, busca-se matar o direito e sua sequência no ato mesmo de ser aluno da escola de nível médio. Alija-se assim a leitura do mundo e suas forças, diante das quais o $\mathrm{eu}$ aquilataria suas possibilidades e aprenderia as relações entre elas e as forças sociais e políticas de que passa a fazer parte. Freire e Heller voltam a ser presentes.

Enquanto em Freire é patente uma sugestão mediadora vinda daquele que tem o dom de olhar todo o espaço habitado e que, a partir de certo momento, entra em comunhão com o povo do vale, em Heller não se distanciam as forças do eu e da sociedade, mas elas devem se conhecer e reconhecer como força e como figura de força. Ora, não há efetiva visão do vale da educação brasileira a partir da redemocratização nos anos de 1980. Na ditadura (1964-1985) sequer havia um vale visível e habitado dada a força repressiva e o acobertamento do possível e do viável. No entanto, já no tempo democrático, o que foi proposto pelo Estatuto da Criança e do Adolescente, 1990, isto é, que crianças e adolescentes são sujeitos da vida e seus direitos; mais que nunca, do seu processo de educação.

Entende-se, pois, a liberdade e os interesses dos serviços educacionais privatistas e luxuosos de experiências educacionais e as mais que duvidosas Organizações Não Governamentais (ONG) da educação que se colocam como best sellers midiáticos a orientar os governos e o estado brasileiro em matéria educacional. A verdade delas se define a priori, no interior de sua construção ideológica e não nos campos de batalha do cotidiano educacional, onde as verdades são expostas e confrontadas.

Põe-se de lado, portanto, aquele pensamento dialético que se realiza nas considerações do estrangeiro do poema de Freire. Nesse, somente se chega a um discurso adequado depois de muita elaboração, além de atos de sinergia e análises dos habitantes e do uso de seus potenciais. $\mathrm{O}$ adolescente do ensino médio brasileiro é sujeito oculto, invisível.

A imposição cognitiva dos exames massivos, inclusive o Pisa, nem de longe respeita o fato de que as melhores competências do novo adolescente serão aquelas hauridas de suas descobertas do eu social que ele representa e das forças sociais que o constituem em direção à sua representação política, ou sua consciência de sujeito educacional. Considera-se, pois, que o cotidiano 
educacional que prepara adolescentes para exames massivos atrasa em muito a sua constituição de sujeito político.

Cabe aqui apresentar a mais densa pesquisa quali-quanti realizada nos últimos anos no Brasil. Abramovay e colegas (2015) acompanharam, ouviram, testaram e dialogaram com adolescentes e jovens da escola pública, de que resulta uma obra indispensável.

Os grupos focais, realizados em dezenas de cidades brasileiras, das várias regiões, revelam os diversos fenômenos do cotidiano que levam os estudantes do Ensino Médio, da Educação de Jovens e Adultos e do Pró-Jovem Urbano (compensatório de ensino médio) a continuar na escola, desistir, faltar, abandonar, ter prazer, enfadar-se: falta de professores, aulas monótonas para estudantes trabalhadores, brigas, doença em família, trabalho, gravidez, cansaço, tráfico de drogas, total desestímulo familiar, falta de perspectiva de futuro; enfim, um universo de fatos e condições que, se por um lado representam a realidade cotidiana da juventude estudantil brasileira do ensino médio, por outro lado sugerem sua saída, pois há falas que analisam o real vivido e buscam compreendê-lo e a respeito do bom trabalho de certos professores, bem como sobre o convívio agradável no interior da escola e a leitura do tempo futuro na vida do indivíduo que se diferencia da família "que não estudou".

Alguns textos de Abramovay (2015) precisam ser conhecidos por quem educa, especialmente por quem ama a juventude e a escola. Toda a primeira parte, em que se caracteriza a juventude presente pode ser associada ao excerto encontrado:

Há que também considerar que os jovens de hoje experimentam um processo de "adultização" acelerado, estando expostos a vulnerabilidades sociais e a múltiplos desafios. São eles - talvez mais do que qualquer outro grupo populacional que enfrentam as maiores incertezas e os riscos advindos do processo de globalização. Para Reguillo (2000), o século XXI assiste a uma crise político-social, excluindo os jovens latino-americanos de um projeto futuro:

[Os jovens do século XXI] de maneiras diversas e desiguais, seguem despedaçando as certezas e continuam assinalando também, através de diversas maneiras, que o projeto social privilegiado pela modernidade na América Latina foi, até hoje, incapaz de realizar as promessas de um futuro inclusivo, justo e, sobretudo, possível (REGUILLO, 2000, p. 3, tradução nossa ${ }^{13}$ ). (p. 26)

No entanto, pouco depois, à página 30 da obra, a autora mexicana, conhecida estudiosa de juventudes, faz séria crítica à escola que conhece, a latino-americana: 
a escola se erige como fiscal, juiz e jurado, mas dificilmente se assume como parte da problemática das culturas juvenis, e menos ainda como propiciadora dessa problemática . . . A dimensão expressiva das culturas juvenis se reduz a um comportamento tresloucado de "não crianças", "não adultos", e suas práticas e leituras do mundo nos dão pistas-chaves para decifrar possíveis configurações que assumem a sociedade. (Reguillo, 2000, citada em Abramovay, 2015, p. 30)

Sobre o entorno tecnológico da juventude, foi feliz a equipe em citar MartínBarbero (2006) e outros, estudiosos das mediações culturais operadas na sociedade pela mídia e seus ecos operacionais, seja no cotidiano, seja nos eventos de que tomam parte as novas gerações:

Numa reestruturação do que entendemos por conhecimento, das fontes e dos critérios de verdade, e dos sujeitos autorizados e reconhecidos como produtores do conhecimento. E essa reestruturação não pode deixar incólume a escola, porque é uma instituição baseada em outro tipo de organização do saber, hierárquica e centralizada. Os educadores que aderem a esta posição sustentam que estamos diante de uma mudança de época e que se necessita organizar o ensino nos novos traços de produção dos saberes, como são a hipertextualidade, a interatividade, a conectividade e a coletividade (MARTÍN-BARBERO, 2006; DUSSEL \& QUEVEDO, 2011, p. 12). (Abramovay, 2015, p. 31)

O destaque devido ao estudo das relações entre jovens e escola cita Charlot (2001), em texto que fala em tom freiriano:

I) que toda relação com o saber é uma relação de quem aprende com aquilo que aprende e consigo próprio, apropriando-se sempre de algo do "mundo humano". O sentido e o valor do que é aprendido "está indissociavelmente ligado ao sentido e ao valor que o sujeito atribui a ele mesmo enquanto aprende (ou fracassa na tentativa de aprender)" (CHARLOT, 2001, p. 27);

II) que toda relação com o saber é uma relação com o outro, pois o aprender dá acesso à comunidade virtual e presente dos que aprendem;

III) que toda relação com o saber é uma relação com o mundo em que a pessoa vive, aprende e desenvolve atividades. "O sujeito não interioriza passivamente o mundo que lhe é oferecido, ele o constrói” (CHARLOT, 2001, p. 27). Tais aprendizagens são mais ou menos importantes, mais ou menos interessantes para o sujeito. 
"O sentido e o valor de um saber ... são indissociáveis dessa relação com o mundo" (CHARLOT, 2001, p. 27-28). (Abramovay, 2015, p. 36)

Antes de destacar alguns resultados dos grupos focais no interior da pesquisa, convém apresentar dados dispostos na obra que têm bastante a ver com as preocupações aqui desenvolvidas, isto é, as dimensões sociais, coletivas e plurais que estimulam a presença da juventude do ensino médio na escola.

A adolescência do ensino médio valoriza a escola como lugar de, pela ordem: ter amigos, participar de aulas legais, realizar passeios com a turma e estudar temas relacionados com a sua vida. Do mesmo modo, professores constatam os mesmos desejos em seu cotidiano.

O que pensam os estudantes da escola foi uma dimensão qualitativa de justo destaque na pesquisa.

Emblemática da relação entre a manutenção do cotidiano e o despertamento para o novo é a leitura do trabalho dos professores, como se lê nas falas de estudantes do Ensino Médio:

A gente percebe quando o professor não gosta de dar aula. Quando ele está ali porque se formou numa profissão, achou que ia encontrar um trabalho numa área e não conseguiu e acabou sendo professor. A gente percebe, é visível aquele professor que gosta, que ele se esforça, que ele fala: - Não, você está com dificuldade, eu vou te ajudar, a gente vai sentar junto, você vai conseguir tirar essa dúvida. Chega com o colega que sabe mais e diz: - Vocês sentam os dois juntos. Então é aquele professor que gosta do que faz. Esse é um bom professor. (2) (Debate Grupo Focal Ensino Médio, Cuiabá). (Abramovay, 2015, p. 114)

Há uma crise na relação de autoridade. A compreensão genérica do poder do magistério está em ruínas no ensino de adolescentes e jovens, como mostra a pesquisa. No entanto, visto que não se trata de posição universal, de fato há brechas para uma nova consciência do trabalho do educador/professor, pois via de regra os estudantes sentem a necessidade precípua do mentor, do orientador, do abridor de novas perspectivas, o que muitas vezes não se encontra no cotidiano limitado da escola, da comunidade e do trabalho. Mas os professores, especialmente no Ensino Médio e nos programas paralelos para os públicos jovem e adulto estão sob rígida análise de seu procedimento, de sua leitura educacional do mundo, de suas atitudes didático-pedagógicas. O que é bom para a saída das leituras genéricas para a consciência de relações sociais na comunidade escolar e, por consequência, para a construção de identificações pessoa que estuda e trabalha e que já se encaminha para a consciência de cidadania. 
Outra fala de estudante é exemplar desse processo:

A semana passada o professor de Geografia, conversou com a gente, aí ele estava explicando que o nosso modelo de ensino é muito antigo, é jesuíta. Aí ele falou que a gente devia aprender outras coisas, por isso que a gente gosta da aula dele, que a aula dele é uma geografia diferente. Aí eu fiquei pensando nisso, falei "nossa, aprende na escola, mas o que a gente aprende não é o que a gente devia aprender mesmo, sobre o mundo, sobre a vida que a gente vai ter, e a gente aprende da vida na rua e não dentro da escola" (Grupo Focal Ensino Médio, Rondonópolis, MT). (Abramovay, 2015, p. 135)

"Aí eu fiquei pensando.... O mundo e a vida se encontram no afloramento do pensamento, entre espontâneo e sistemático, por impulso do diálogo que também o cotidiano possibilita. A interação havida no curso de geografia dessa escola provê uma força individual que começa a se encontrar com forças sociais na vida do mundo, o que poderá levar à capacidade política de pensar a sociedade.

Quando a equipe dispôs construtos comportamentais, houve reações diversas, quer pela crítica a colegas, quer a professores, especialmente pela falta de boas explicações sobre as matérias, de compreensão das individualidades, do fluxo de raivas reprimidas e espalhadas contra pessoas do convívio escolar.

Concluem os pesquisadores coordenados por Abramovay (2015):

Impressiona, não por ser específico desta pesquisa, mas por ser indicador de uma cidadania cultural negada, a escassez de alternativas para se divertir, para ter prazer e regular seu ritmo de vida, campo da pesquisa extensiva e presente nas narrativas de jovens. Teatro, museus e viagens são pouco citados; as festas coletivas se restringem, com maior probabilidade, a shows de música popular gratuitos e a reuniões em casa de amigos. Cinema também aparece pouco, especialmente entre jovens do EM. Esses, em maior número, sabem melhor usar a Internet que os da EJA e do PJU. Os jovens chegam à escola sem um capital cultural, que, por sua vez, também não faz parte da agenda dessa, predominando uma socialização incompleta, que compromete o processo de conhecimento. (p. 232)

O que têm os e as jovens-adolescentes a ver com a agenda vazia que o sistema nacional de educação faz cair nas escolas que ministram o ensino médio? Cabe-lhes alguma culpa, para usar o jargão dessa sociedade que lava as próprias mãos e encontra nos outros mãos barreadas de um cotidiano tornado tanto incompreendido quanto inconsciente? 
Como parte dos estudos que levaram à constituição da Base Nacional Comum Curricular (BNCC) (2017-2018), isto é, BNCC do Ensino Fundamental e BNCC do Ensino Médio, a Câmara de Educação Básica do Conselho Nacional de Educação (CNE) preparou uma síntese das Diretrizes Curriculares Nacionais (DCN), algumas delas preparadas por membros das comissões originais das Diretrizes. Foi o caso das DCN do Ensino Médio, relatada em 2011 pelo conselheiro José Fernandes Lima, que também preparou a síntese.

Nela há clareza de como e por que trabalhar com os adolescentes e jovens dessa etapa decisiva na direção do mundo adulto, incluídas as relações de trabalho e, como direito, a universidade.

Lê-se:

sugere-se que, para viabilizar o atendimento a todos os estudantes do Ensino Médio, faz-se necessário discutir as características sócio-econômico-culturais dos jovens que o frequentam; entender as representações que a escola, seus professores e dirigentes fazem dos estudantes; saber quais sentidos e significados os jovens atribuem à experiência escolar; conhecer como os jovens interagem com a diversidade e em que medida a cultura escolar instituída se aproxima ou se distancia das expectativas dos jovens estudantes.

Além disso, é importante verificar se a experiência escolar oferecida guarda alguma relação com os interesses pessoais e os projetos de vida dos estudantes; identificar em que medida as atividades desenvolvidas na escola podem contribuir para que os estudantes elaborem seus projetos de futuro; e verificar se há aspectos que necessitam ser modificados no sentido de favorecer a permanência dos estudantes, com sucesso, na escola. (Síntese das Diretrizes Curriculares Nacionais para a Educação Básica, s.d., p. 37)

Em decorrência dessa leitura sociopsicológica, que provê a educação do dia a dia dos adolescentes e jovens, quem educa deve considerar que eles e elas têm voz, pensam, planejam, escolhem e julgam, não somente na pragmática do que qualquer escola oferece, mas na direção de seu destino como pessoa e cidadão, cidadã. As poucas falas escolhidas do texto de Abramovay (2017) dão conta dessas atitudes.

Portanto, pela ótica da imagem política, o ensino médio é um gargalo, o que demonstra a ignorância dos estamentos burocráticos. Pela ótica do diálogo em pesquisa, trata-se de um lugar esvaziado pelo sistema nacional de educação, incompreendido tanto na sua diversidade quanto nos percursos formativos 
assumidos pelos sujeitos-estudantes e, mais ainda, pela ausência da arte, da ética, da beleza, do prazer e da segurança gerida comunitariamente.

\section{PALAVRAS FINAIS}

A consciência humano-genérica feita social e política proposta em Heller exigiria retomada dos debates de 2016 e questionamento da lei que, basicamente, ainda está no papel, especialmente nos Estados mais pobres. Ato contínuo, sem que os próprios adolescentes sejam consultados, nenhuma base nacional comum alcançará o que Freire entende como o ensino realizado no encontro com os outros e no confronto com o mundo, visto que este se inicia no eu da juventude e não nas imagens pervertidas (e escurecidas) dos estamentos dirigentes. É de se crer que a releitura atenta - e nacional - das Diretrizes Curriculares Nacionais para o Ensino Médio, associadas às Diretrizes específicas para a educação afrodescendente, indígena, quilombola, nômade, ribeirinha, especial e dos espaços periféricos (Diretrizes Curriculares Nacionais Gerais da Educação Básica, 2013) traga valores, desafios e orientações seguras ao documento da BNCC Ensino Médio e, desse modo, se entenda e se tome consciência de que todo currículo dessa etapa deve ser integral, expandido e capaz de garantir autonomia, liberdade e caminho de cidadania, com pleno exercício dos talentos e vocações da adolescência. Aí já se realiza uma etapa pensada em Freire e entendida como um movimento para a humanização. No contexto das histórias culturais do Brasil, humanização como pensada em Pedagogia do Oprimido (o Manuscrito) - é ato revolucionário.

A pandemia exacerbou todas as ruindades e os defeitos do sistema. Mas esclareceu bastante. Na releitura de Abramovay (2015), há sinais de elementos inéditos - e viáveis - em disputa na sociedade: $\mathrm{o}$ fim da escola fragmentada, em que professores muitas vezes são inimigos de alunos e na qual outras cizânias cumprem seu papel de fortalecimento da inconsciência ou da consciência infeliz, a favor de uma escola dotada de outra palavração e várias inclusões que fortaleçam laços sociais, espírito de pesquisa, descoberta de narrativas do povo do entorno, do bairro e da cidade, foco nas ciências e nenhum descuido quanto aos saberes do povo. Isso significa a comunidade educadora, de fato e em verdade a criadora, mantenedora e avaliadora de currículos integrais de estudos, projetos didático-pedagógicos e regimentos escolares nitidamente democráticos. Cada escola é lugar de análise do Brasil e de proposição de mudanças no país, que não tem mais desculpas para a manutenção de feudos, capitanias, colônias e impérios. Por isso, pensar educação de nível médio implica pensar a revolução na sociedade sistematicamente injusta. 
Nas propostas de Paulo e Agnes, cujo humanismo/humanização se traduz em revolução de amor que se dirige às novas gerações, o inédito se faz viável e as necessidades do indivíduo cotidiano se soltam em rota de mudança da consciência iluminada no interior do mesmo cotidiano, mas com a clareza do devir social e político, isto é, do direito ao exercício dos talentos e vocações na cidade, no campo agriculturável, no rio, na floresta, no quilombo.|MI

\section{REFERÊNCIAS}

Abramovay, M. (Coord.). (2015). Juventudes na escola, sentidos e buscas: Por que frequentam? Flacso - Brasil; OEI; MEC. https://bit.ly/3FctUtS

Alves, L. R. (1997). Diálogos de amor: Humanismo e exílio em Iehuda Abravanel. Fapesp; Edusp; Nova Alexandria.

Bauer, M., \& Aarts, B. (2002). A construção do corpus: Um princípio para a coleta de dados qualitativos. In M. Bauer \& G. Gaskell (Eds.), Pesquisa qualitativa com texto, imagem e som: Um manual prático (pp. 39-63). Vozes.

Burckhardt, J. (2009). A cultura do Renascimento na Itália. Companhia das Letras. (Trabalho original publicado em 1868)

Charlot, B. (Org.). (2001). Os jovens e o saber: Perspectivas mundiais. Artmed. Chartier, R. (1990). A História Cultural entre práticas e representações. Difel.

Diretrizes Curriculares Nacionais Gerais da Educação Básica (2013). Ministério da Educação; Secretaria de Educação Básica; Diretoria de Currículos e Educação Integral https://bit.ly/3FgdDE9

Freire, P. (1983). Educação e mudança (12a ed.). Paz e Terra. (Trabalho original publicado em 1979)

Freire, P. (1996). Pedagogia da autonomia. Saberes necessários à prática educativa (2a ed.). Paz e Terra.

Freire, P. (2001). Pedagogia dos sonhos possíveis (A. M. A. Freire, Org.). Editora Unesp. Freire, P. (2018). Pedagogia do oprimido (o manuscrito) (J. F. Mafra, J. E. Romão \& M. Gadotti, Orgs.). Editora e Livraria Instituto Paulo Freire; Universidade Nove de Julho (Uninove); Big Time Editora/BT Acadêmica. https://bit. ly/2ZOVMUB

Gadotti, M. (1983). Prefácio: Educação e orden classista. In P. Freire, Educação e mudança (12a ed.) (pp. 9-14). Paz e Terra. (Trabalho original publicado em 1979)

Garin, E. (Org.). (1993). L'uomo del Rinascimento (6a ed.). Laterza. (Trabalho original publicado em 1988)

Heller, A. (1982). O homem do Renascimento. Editorial Presença. (Trabalho original publicado em 1967) 
Heller, A. (1985). O cotidiano e a história (2a ed.). Paz e Terra. (Trabalho original publicado em 1970)

Heller, A. (2011). La teoria, la prassi e i bisogni umani. In E. Bazzanella (Ed.), Ágnes Heller tra Marx e Foucault (pp. 27-48). Abiblio. (Trabalho original publicado em 1972)

Heller, A. (2012). I miei occhi hanno visto. Con Francesco Comina e Luca Bizzarri. Il Margine.

Heller. A. (1977) La sociologia de la vida cotidiana. Edicions 62. (Trabalho original publicado em 1970)

Hobsbawn, E. (2007). A era das revoluções. Europa, 1789-1848. Paz e Terra.

Lukács, G. (1977). Prefacio. La sociologia de la vida cotidiana (pp. 6-14). Edicions 62. (Trabalho original publicado em 1970)

Martín-Barbero, J. (2006). Tecnicidades, identidades, alteridades: Mudanças e opacidades da comunicação no novo século. In D. Moraes (Org.), Sociedade midiatizada (pp. 51-79). Mauad.

Marx (1969). La cuestión judía. Ediciones Coyoacán. (Trabalho original publicado em 1844)

Sartre, J.-P. (1970). Lexistentialisme est un humanisme. Les Éditions Nagel.

Síntese das Diretrizes Curriculares Nacionais para a Educação Básica. (s.d.). https://bit.ly/3D9JKU1

\section{APÊNDICE: POEMA SEM TÍTULO DE PAULO FREIRE}

Depois de algum tempo de chegado,

o estrangeiro disse aos homens do vale

num morrer da tarde:

Até agora vos tinha falado apenas

dos cânticos dos pássaros e

da ternura das madrugadas.

Era preciso fazer convosco um aprendizado fundamental:

sentir a incerteza do amanhã

vivendo a negação de mim mesmo,

num trabalho que não é nosso.

Só assim falar a vós seria uma forma de falar convosco.

Agora vos digo:

não acreditemos em quem proclame

que nossa fraqueza é um presente dos deuses;

que ela está em nós como o perfume nas flores

ou o orvalho nas manhãs 
Nossa fraqueza não é ornamento

de nossas vidas amargas.

Não acreditemos nos que afirmam

com hipócrita entonação,

que a vida é assim mesma;

- uns poucos podendo muito,

milhões nada podendo.

Nossa fraqueza não é virtude.

Façamos de conta, porém, que acreditamos

em seus discursos.

É preciso que nenhum gesto nosso

revele nossa intenção real.

É preciso que eles partam felizes com sua mentira;

certos de que somos coisas suas.

Necessitamos de tempo

para preparar o nosso discurso

que sacudirá montanhas e vale

mares e rios

e os deixará atônitos e medrosos.

Nosso discurso diferente

- nossa palavração - será dito

por nosso corpo todo:

nossas mãos, nossos pés, nossa reflexão.

Tudo em nós falará uma linguagem

criadora de vida

- inclusive os instrumentos que

nossas mãos usarão,

quando, em comunhão

transformarmos nossa fraqueza

em nossa força.

Ai de nós, porém, se pararmos de falar,

Somente porque eles já não possam mais mentir.

Por isto vos digo:

Nosso discurso de libertação

não é medicina para doença passageira.

Se emudecermos ao se calarem

as mentiras atuais

novas mentiras surgirão

em nome de nossa libertação. 
Nosso discurso diferente,

- nossa palavração -

como discurso verdadeiro,

se fará e re-fará;

jamais é ou terá sido

porque sempre estará sendo.

Nosso discurso diferente,

- nossa palavração -

tem de ser um discurso permanente.

Paulo Freire, Genebra, abril de 1971

Do acervo de Ana Maria Araújo Freire. Inserto, na apresentação, em Freire (2001).

Artigo recebido em 9 de junho e aprovado em 2 de agosto de 2021. 